\title{
Qualitative Analysis of Carbon Emissions and Offsetting Opportunities of Zalaegerszeg Automotive Proving Ground
}

\author{
Tamás Pálvölgyi1, Tibor Princz-Jakovics, László Valkó1, Kálmán Kósi', András Háry² \\ ${ }^{1}$ Department of Environmental Economics and Sustainability, Faculty of Economic and Social Sciences, Budapest University of \\ Technology and Economics, Magyar tudósok körútja 2., H-1117 Budapest, Hungary \\ 2 Automotive Proving Ground Zala Ltd., Fészek street 4., H-8900 Zalaegerszeg, Hungary \\ *Corresponding author, e-mail: princz-jakovics.tibor@gtk.bme.hu
}

Received: 27 May 2020, Accepted: 08 July 2020, Published online: 10 February 2022

\begin{abstract}
The aim of this paper is to provide an overview about the efforts of the management board of the Automotive Proving Ground in Zalaegerszeg to decrease carbon effects, which is in a close relation with the project level sustainability opportunities of this special investment. Based on the research work we have done, solutions were proposed to achieve the vision of "net zero (or negative) emissions" of this project. In the investigations concerning the test track, system boundaries were defined such that all relevant facilities and processes operating were considered. In emissions calculations, we have employed the procedure outlined by the GHG Protocol for 3 scopes and the employed methodology relied heavily on the related standard. For the calculations, the definition and collection of input data types was the first step. Then the assessment has been conducted by taking into consideration the geometric shape of test platforms, anticipated vehicle loading of track elements, typical distance-speed diagrams, as well as the utilized vehicle types (passenger cars, trucks and buses). We calculated $\mathrm{CO}_{2}$-equivalent emissions from gasoline and diesel fuel consumptions (from the product of fuel demand and conversion factors), using "Tank-to-Wheels" and "Well-to-Wheels" approaches. Based on the emission calculations carbon offsetting opportunities were analyzed to assume the effect of $\mathrm{CO}_{2}$ emissions reduction and capture: forestation and green surface development; energy crop plantation and heat generation; establishment of a photovoltaic (PV) farm (electricity production). We have shown the main characteristics of the 3 main options and their advantages and disadvantages.
\end{abstract}

\section{Keywords}

Automotive Proving Ground, calculation of carbon emissions, GHG Protocol, carbon offsetting

\section{Introduction}

The Automotive Proving Ground in Zalaegerszeg (APZ) is a unique investment in Hungary consisting of various research, development and innovation infrastructure elements. The proving ground provides not only test facilities for conventional vehicles, but it allows validation testing of autonomous and electric vehicles, as well.

This research conducted was primarily concerned with the institutional requirements of sustainability of the test track. In particular, the mitigation of greenhouse gas emissions, considered to be the root cause of climatic changes, was treated as having a crucial role among sustainability objectives (see also in Transport \& Environment, 2018). Not only the nation-wide assessment of long term carbon effects of transport activities are important (Török et al, 2017), our research objective is interlinked with the vision of "net zero (or negative) emissions" of this project on a corporate level.

\section{Methodology}

In the investigations concerning this test track, system boundaries are defined such that all relevant facilities and processes operating are considered, regardless of their full or partial ownership or operation by the organization. In emissions calculations, we have employed the procedure outlined by the GHG Protocol (WBCSD and WRI, 2004). This protocol proposes the following steps for conducting the investigations:

- Scope 1: Direct GHG emissions occur from sources that are owned or controlled by the company.

- Scope 2: indirect GHG emissions (e.g., purchased electricity consumed)

- Scope 3: other indirect GHG emissions (e.g., all other purchased materials, including fuels)

The employed methodology relies heavily on the standard MSZ EN 16258:2013 titled "Methodology for calcu- 
lation and declaration of energy consumption and $G H G$ emissions of transport services (freight and passengers)" (MSZT, 2013).

For the calculations, the definition and collection of input data types was necessary. These can be grouped as follows:

- Input data related to the operation of vehicles and transportation:

1. definition of tested vehicle types,

2. main technological parameters of engines,

3. fuel consumption by vehicle type.

- Input data required for the calculation of emissions from buildings and service facilities are the following:

1. electricity consumption of buildings (lighting, operation of electrical systems),

2. heating and cooling energy consumption of buildings,

3. water consumption.

The assessment has been conducted by taking into consideration the geometric shape of test platforms, anticipated vehicle loading of track elements, typical distance-speed diagrams, as well as the utilized vehicle types (passenger cars, trucks and buses). Estimation of $\mathrm{CO}_{2}$ equivalent emissions from gasoline and diesel fuels was performed using conversion factors, employing the Tankto-Wheels and Well-to-Wheels approach, using daily and annual figures. As testing is to be performed based on the specific requirements of the manufacturers, at this stage, preliminary data estimates of planned tests are available. During the investigation phase, real fuel consumption measurements of test vehicles were not available, that is why the following estimation approach was adopted in carrying out the calculations:

1. Mileage and specific fuel consumption determined by vehicle type; specific fuel consumption values were determined based on speed profiles and the scaling of three consumption types (normal, high, extraordinary), validated by real test consumption data.

2. Daily fuel demand was calculated.

3. Conversion factors were used in both Tank-toWheels and Well-to-Wheels approaches.

4. Emission estimations were aggregated daily and annually, using both the Tank-to-Wheels and Wellto-Wheels approaches, considering 160 days of operation annually, with tests peaking out by 2025 .

The main geometric characteristics of the test platforms, as well as the anticipated vehicle loads of track elements are presented in Tables 1 and 2, respectively. The complexity of track elements is also indicated (e.g., the vehicle dynamics platform consists of an accelerating lane and a circular test track, the braking platform consists of an accelerating lane and parallel track sections). Maximum testing speeds fall within the range of $50 \mathrm{~km} / \mathrm{h}$ to $200 \mathrm{~km} / \mathrm{h}$, depending on the nature of the test, the track platform geometry and structural characteristics. Maximum testing capacity is within the range of 10 vehicles per hour to 200 vehicles per hour, with a safe operating capacity of $5-25 \%$. Vehicle numbers refer to all vehicle categories combined.

Table 1 Main characteristics of test platforms (dimensions, length, layout) (data provided by APZ)

\begin{tabular}{|c|c|c|c|}
\hline \multirow[t]{2}{*}{ Test elements } & \multicolumn{3}{|c|}{$\begin{array}{l}\text { Characteristics of test platforms } \\
\text { (dimensions, length, layout) }\end{array}$} \\
\hline & Description & $\mathrm{m}$ & Total \\
\hline \multirow[t]{2}{*}{ Dynamic Platform (DP) } & $\begin{array}{l}\text { Accelerating } \\
\text { section (length) }\end{array}$ & 700 & 1000 \\
\hline & $\begin{array}{l}\text { Round section } \\
\text { (diameter) }\end{array}$ & 300 & \\
\hline \multirow[t]{2}{*}{ Braking Platform (BP) } & Accelerating lane & 700 & 900 \\
\hline & Parallel sections & 200 & \\
\hline $\begin{array}{l}\text { Handling Course } \\
\text { (High Speed) (HCHS) }\end{array}$ & High speed section & 2000 & 2000 \\
\hline $\begin{array}{l}\text { Handling Course } \\
\text { (Low Speed) (HCLS) }\end{array}$ & Low speed section & 1000 & 1000 \\
\hline Urban testing environment & Urban links & 3000 & 3000 \\
\hline Rural Road (RR) & & & 5000 \\
\hline Road in "bad condition" & & $150-200$ & 200 \\
\hline Ramp & & & 400 \\
\hline $\begin{array}{l}\text { High Speed Oval (HSO) } \\
\text { track platform }\end{array}$ & & & 4400 \\
\hline
\end{tabular}

Table 2 Main traffic characteristics of test platforms (maximum speed, capacity, capacity use) (data provided by APZ)

\begin{tabular}{lcc}
\hline Test elements & $\begin{array}{c}\text { Max. testing } \\
\text { speed }(\mathrm{km} / \mathrm{h})\end{array}$ & $\begin{array}{c}\text { Max. capacity } \\
\text { (vehicle/hour) }\end{array}$ \\
\hline $\begin{array}{l}\text { Dynamic Platform (DP) } \\
\text { Braking Platform (BP) }\end{array}$ & 100 & 30 \\
$\begin{array}{l}\text { Handling Course } \\
\text { (High Speed) (HCHS) }\end{array}$ & 120 & 100 \\
$\begin{array}{l}\text { Handling Course } \\
\text { (Low Speed) (HCLS) }\end{array}$ & 60 & 100 \\
$\begin{array}{l}\text { Urban testing environment } \\
\text { Rural Road (RR) }\end{array}$ & 60 & 50 \\
Road in "bad condition" & 100 & 200 \\
Ramp & 100 & 100 \\
$\begin{array}{l}\text { High Speed Oval (HSO) } \\
\text { track platform }\end{array}$ & 50 & 100 \\
\hline
\end{tabular}


Test platforms operate for ten hours daily, thus, total daily vehicle numbers amount to tenfold the average hourly load figures.

It is expected that the distance-speed diagrams of the tests performed on the various track sections provide valuable input for calculations. The distance-speed diagrams for three test platforms are presented in Fig. 1, and a general description of the speed profiles of the other platforms are the follows:

- Handling Course (HCHS and HCLS): racetrack-style profile for 50 to $140 \mathrm{~km} / \mathrm{h}$ for light vehicles, or 40 to $90 \mathrm{~km} / \mathrm{h}$ for heavy vehicles;

- Urban testing environment: normal urban speed profile;

- Rural Road (RR); "Poor conditioned" road and ramp: normal speed profile for rural roads.

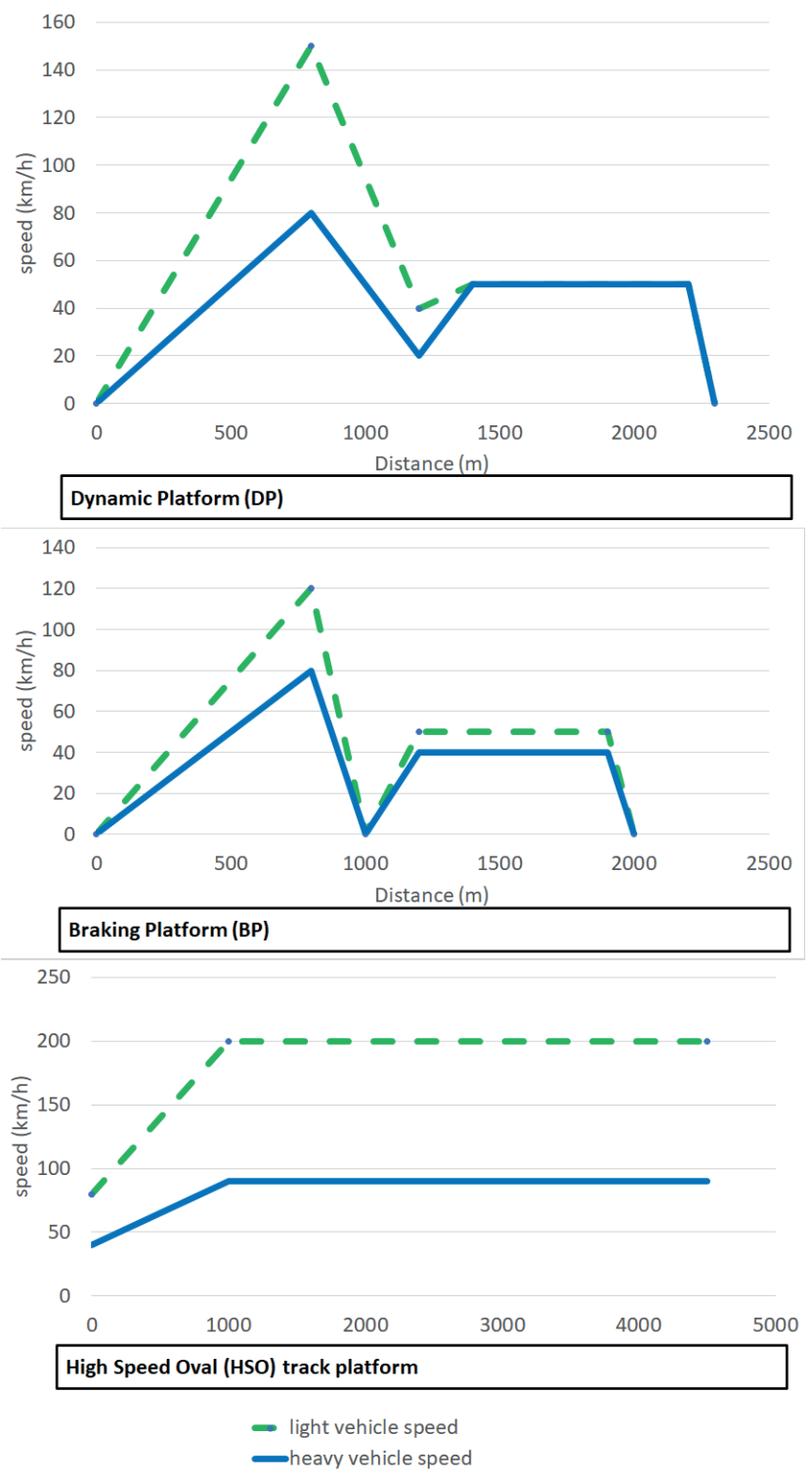

Fig. 1 Distance-speed diagrams (data provided by APZ)
As specific fuel consumption and emissions are different for petrol and diesel vehicles, these two fuel types should be treated separately from each other. The proportion of use by vehicle category is demonstrated in Table 3. These figures have been complemented by the share of diesel passenger cars (based on figures from the Hungarian Central Statistical Office, (HSO, 2018)), some 32\% of newly registered road legal passenger cars were diesel-powered). From this, the total share of diesel and gasoline vehicles can now be estimated (supposing that trucks and buses are $100 \%$ diesel-powered). At the current stage, the emissions of the $5 \%$ share of hybrid and electric vehicles was ignored. However, in a longer term the share of electric vehicles will rapidly increase in Hungary (ITM, 2019) that is why the calculation of the carbon effects of such test vehicles should be the subject of another research

\section{Results and primary conclusions of the emission calculations by vehicle categories}

Calculations were performed based on the methodology and input data stated previously, by first estimating the aggregate daily displacement. This was calculated by taking the product of the length of the test platform, the anticipated traffic volume at peak testing capacity, and ten hours of daily operations. Aggregate daily displacement figures for each test platform are shown in Table 4.

Test operating cycles were split into three main consumption categories (normal, high and extraordinary), and the percentage share of each category, with specific fuel consumption values, was determined. This has enabled the use of the appropriate approximations for each type of testing. The consumption categories employed are the following:

- normal consumption: normal, steady driving on rural or urban road speeds;

- high consumption: multiple accelerations and higher speeds;

- extraordinary: many accelerations, extremely high speeds or congested urban driving.

Table 3 Share of propulsion type by vehicle category (own calculations)

\begin{tabular}{|c|c|c|c|c|c|}
\hline \multirow[t]{2}{*}{ Category } & \multirow[t]{2}{*}{ Share } & \multicolumn{2}{|c|}{$\begin{array}{c}\text { Fuel share } \\
(100 \% \text { : category) }\end{array}$} & \multicolumn{2}{|c|}{$\begin{array}{l}\text { Fuel share } \\
\text { (100\%: total } \\
\text { vehicles) }\end{array}$} \\
\hline & & Diesel & Gasoline & Diesel & Gasoline \\
\hline Car & $75 \%$ & $32 \%$ & $68 \%$ & $24 \%$ & $51 \%$ \\
\hline $\begin{array}{l}\text { Heavy duty } \\
\text { vehicle (truck) }\end{array}$ & $15 \%$ & $100 \%$ & & & \\
\hline Bus & $5 \%$ & $100 \%$ & & & \\
\hline $\begin{array}{l}\text { Hybrid, } \\
\text { electric vehicle }\end{array}$ & $5 \%$ & & $\mathrm{t}$ taken int & consider & tion \\
\hline
\end{tabular}


Table 4 Aggregate displacement and weighted fuel consumption figures by vehicle category (own calculations)

\begin{tabular}{lcccc}
\hline Test elements & $\begin{array}{c}\text { Total } \\
\text { distance }\end{array}$ & \multicolumn{3}{c}{ Consumption } \\
& $\begin{array}{c}\text { Vehicle- } \\
\text { km/day }\end{array}$ & $\begin{array}{c}\text { Diesel } \\
(1 / 100 \mathrm{~km})\end{array}$ & $\begin{array}{c}\text { Gasoline } \\
(1 / 100 \mathrm{~km})\end{array}$ & $\begin{array}{c}\text { Diesel } \\
(1 / 100 \mathrm{~km})\end{array}$ \\
\hline $\begin{array}{l}\text { Dynamic } \\
\text { Platform (DP) }\end{array}$ & 123.15 & 21.00 & 25.20 & 105.00 \\
$\begin{array}{l}\text { Braking } \\
\text { Platform (BP) }\end{array}$ & 190.00 & 21.00 & 25.20 & 105.00 \\
$\begin{array}{l}\text { Handling } \\
\text { Course (High }\end{array}$ & 380.00 & 9.00 & 10.80 & 42.50 \\
$\begin{array}{l}\text { Speed) (HCHS) } \\
\text { Handling }\end{array}$ & & & & \\
$\begin{array}{l}\text { Course (Low } \\
\text { Speed) (HCLS) }\end{array}$ & 380.00 & 7.00 & 8.40 & 37.50 \\
$\begin{array}{l}\text { Urban testing } \\
\text { environment }\end{array}$ & 300.00 & 8.50 & 10.20 & 45.00 \\
$\begin{array}{l}\text { Rural Road } \\
\text { (RR) }\end{array}$ & 2000.00 & 8.00 & 9.60 & 31.25 \\
$\begin{array}{l}\text { Road in } \\
\text { "bad condition" }\end{array}$ & 10.00 & 8.00 & 9.60 & 35.00 \\
$\begin{array}{l}\text { Ramp } \\
\text { High Speed } \\
\text { Oval (HSO) } \\
\text { track platform }\end{array}$ & 40.00 & 9.00 & 10.80 & 42.50 \\
Total & 83.00 & 10.50 & 12.60 & 47.50 \\
\hline & 3351.15 & & & \\
\hline & & & & \\
\hline
\end{tabular}

By weighting the operating cycle values according to the share of the consumption type, a table displaying relative fuel consumption per 100 kilometers of displacement may be drawn up. These values are well in line with the empirical data obtained during real-life test operations.

Fuel demand for test operations by test platform element may be calculated from the total displacement, specific consumption figures and the diesel-to-petrol ratio. Total daily fuel consumption is estimated to be 547.5 liters.

Using the results of fuel demand calculations, emissions can be estimated. For this, conversion factors will be employed as per the standard MSZ EN 16258:2013 (MSZT, 2013), see Table 5.

We calculated $\mathrm{CO}_{2}$-equivalent emissions from gasoline and diesel fuel consumption (from the product of fuel demand and conversion factors), using both approaches. Annual aggregate emission figures are obtained by multiplying daily figures by 160 operating days.

Using the "Tank-to-Wheels" approach, aggregate $\mathrm{CO}_{2}$ equivalent emissions of the test track amount to 226.2 metric tons per annum. Similarly, using the "Well-to-Wheels" approach, aggregate $\mathrm{CO}_{2}$-equivalent emissions of the test track amount to 272.7 metric tons per annum. According
Table 5 Transportation fuels: density, energy factors and GHG emission factors (based on MSZ EN 16258:2013 Table A1 (MSZT, 2013))

\begin{tabular}{|c|c|c|c|c|c|}
\hline \multirow{4}{*}{$\begin{array}{l}\text { Type of fuel } \\
\text { Gasoline }\end{array}$} & \multirow{4}{*}{$\begin{array}{l}\text { Density } \\
\frac{[\mathrm{kg} / \mathrm{l}]}{} \\
0.745\end{array}$} & \multicolumn{4}{|c|}{ Energy factor } \\
\hline & & \multicolumn{2}{|c|}{ Tank-to-wheels } & \multicolumn{2}{|c|}{ Well-to-wheels } \\
\hline & & \multicolumn{4}{|c|}{$\left[\mathrm{kgCO}_{2 \mathrm{e}} / 1\right]$} \\
\hline & & 43.2 & 32.2 & 50.5 & 37.7 \\
\hline \multirow[t]{4}{*}{ Diesel } & 0.832 & 43.1 & 35.9 & 51.3 & 42.7 \\
\hline & & \multicolumn{4}{|c|}{ GHG emission factor } \\
\hline & & \multicolumn{2}{|c|}{ Tank-to-wheels } & \multicolumn{2}{|c|}{ Well-to-wheels } \\
\hline & {$[\mathrm{kg} / \mathrm{l}]$} & \multicolumn{4}{|c|}{$\left[\mathrm{kgCO}_{2 \mathrm{e}} / 1\right]$} \\
\hline Gasoline & 0.745 & 3.25 & 2.42 & 3.86 & 2.88 \\
\hline Diesel & 0.832 & 3.21 & 2.67 & 3.90 & 3.24 \\
\hline
\end{tabular}

to the methodology chosen for this research and taking into consideration that measurements of real fuel consumptions are not available, the estimation of emissions by "Tank-to-Wheels" approach is relevant and can provide basic data for further investigations of carbon offsetting. Results from this approach, for each of the test platforms, are demonstrated in Fig. 2 below. Extremely high values are highlighted in dark gray, primarily caused by great vehicle numbers and long distances on rural road stretches. However, it is predicted that this module will be the most crucial one in testing self-driving, autonomous vehicles.

\section{Opportunities for carbon offsetting}

Carbon offsetting provides an important opportunity for the practical implementation of carbon footprint calculations. In these, activities to the effect of $\mathrm{CO}_{2}$ emissions reduction and capture are analyzed, whereby, under ideal circumstances, if properly scaled, these activities will counterbalance all of the $\mathrm{CO}_{2}$ emissions of this test track. In planning such carbon offsetting, the following principles should be followed:

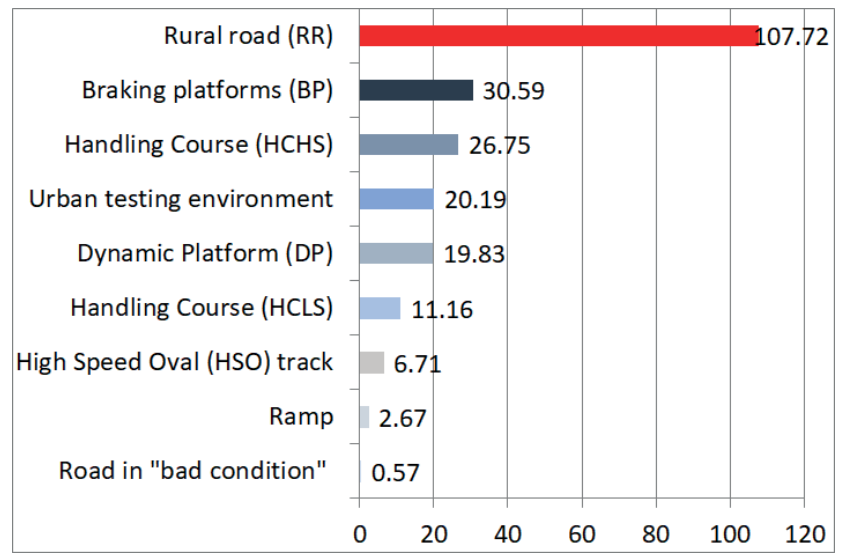

Fig. 2 Annual emissions by test platform, "Tank-to-Wheels" approach (metric tons $\mathrm{CO}_{2 \mathrm{e}}$ /year) (own calculations) 
- Calculation of the carbon footprint of the test track must include all emission sources (and thus not only the test phase), in accordance with the Full Lifecycle Concept of transport infrastructure projects (Dalton et al., 2017). This is the starting point in each carbon footprint calculation that can be found in the Commission recommendation (EU, 2013). This implies that ancillary emissions ought to be estimated also. Nevertheless, systemic boundaries must be defined by the service performed by the test circuit; only those emissions should be considered over which the operator may exercise direct or indirect control.

- Offsetting strategies should not necessarily be restricted to the geographic area of the proving ground. Options, which could be realized on terrain not connected to the test circuit itself, but which may be realized through business plans (contractual agreements) during the operation of the proving ground, should be considered. This solution is widely used (e.g. Oxytree, and numerous projects across Hungary have similarly proven the feasibility of this concept).

- Attempts at $\mathrm{CO}_{2}$ offsetting should be made comparable. An appropriate means of achieving this is the calculation of the decarbonization potential of the offsetting options. Decarbonization potential is defined as the mass of $\mathrm{CO}_{2}$ sequestered or saved by a given offsetting technique over an area of one hectare, with the unit $\mathrm{t}\left[\mathrm{CO}_{2}\right] /$ ha/year.

Considering the experiences in Hungary, the endowment of Zala County, and the opportunities of the proving ground, the following three $\mathrm{CO}_{2}$ offsetting options are evaluated:

1. $\mathrm{CO}_{2}$ sequestration with forestation and green surface development;

2. $\mathrm{CO}_{2}$ offsetting by energy crop plantation and heat generation;

3. $\mathrm{CO}_{2}$ offsetting by the establishment of a photovoltaic (PV) farm (electricity production).

\section{1 $\mathrm{CO}_{2}$ sequestration with forestation and green surface development}

The total land area of the planned facility amounts to 258.8 hectares, which has been previously used in agriculture and forestry, the latter comprising 18 hectares in total.

The total green surface area amounts to some 182 hectares. The task is to analyze the creation of such plant communities which conform to the requirements of safe testing, but equally contribute to the achievement of the sustainability objectives.
Forests play a fundamental role in the global processes of the biosphere, as well as in the shaping of local environmental conditions.

Hungary is situated in the zone of deciduous forests in the temperate climatic zone. Presently, the forestation rate is $20.1 \%$ (HSO, online), whilst before human activities commenced, this rate was $84 \%$. Presently, forests in Hungary are net carbon absorbers, sequestering approximately 4 to 5 million tons of carbon dioxide annually.

Forestry is a multi-functional form of land use, which, besides tackling crucial challenges in combating climate change, satisfies a number of further requirements. These include the protection of biodiversity, soil protection, provision of drinking water, supplying wood for timber or energy, but also, the extension of particular social and recreational functions. Hungary's National Forestry Strategy (FM, 2016) posits that the living communities of forests ought to be managed and used in such a way and to such extent, that they remain functioning ecosystems.

Recognizing the environmental changes stemming from resource overuse, the decline of biological diversity, the increase of structural homogeneity and spatial reductions affecting forests, naturalness has become a crucial factor in the approach towards forests.

In terms of yields, the greatest uncertainty is posed by the local characteristics. The area in question within Zala County does not provide optimal growth conditions for the plantation of forests with greater environmental value, but forestation with a mix of certain oaks is feasible.

Decarbonization calculations are based on the CASMOFOR model (Somogyi, online). Essentially, this model considers the growth (yield) and carbon content of various tree species, giving the $\mathrm{CO}_{2}$ sequestration per hectare. Fig. 3 shows the growth of carbon sink capacities of some key species.

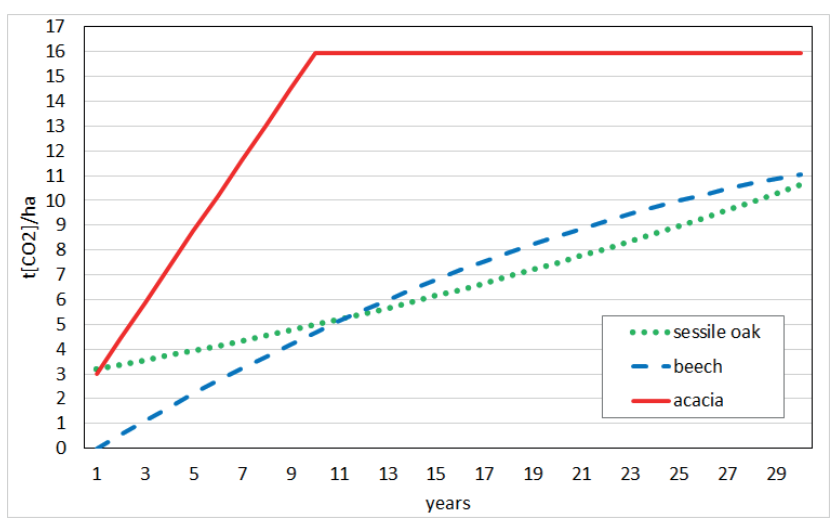

Fig. 3 Estimated $\mathrm{CO}_{2}$ emission's savings by tree's carbon sequestration 
It is important to note that forests only reach their peak decarbonization potential years after plantation, since a recently-planted sapling can sequester less $\mathrm{CO}_{2}$ than a mature tree. Depending on the species, peak decarbonization is reached at different times; acacias reach this peak within approximately 10 years, but for numerous other, environmentally more valuable species (e.g. beech, hornbeam and oak) attaining their peak may take as long as 50 years.

\section{2 $\mathrm{CO}_{2}$ offsetting by energy crop plantation and energy generation}

The most significant advantage of using biomass for energy generation is that it is possible to do so without increasing atmospheric greenhouse gas concentrations. This technology is "carbon-neutral", since only as much carbon dioxide is generated as has been sequestered by the plant during photosynthesis. The carbon dioxide emitted during combustion will be once again sequestered during the next growth cycle; photosynthesis drives this renewal. Storage of solar energy occurs as chemical energy in organic matter created during photosynthesis.

Climatic conditions in Hungary (predominantly winter frosts and cold spells, but also spring droughts) foretell significant uncertainties in yields of soft-stemmed biomass, whilst with other species, such as Chinese silver grass, plantation and investment costs are prohibitively high (Ivelics, 2006).

Yield uncertainties of soft-stemmed energy crops (grasses and reeds) pose a double investment risk if used in a carbon-offset project (Ben Fradj and Jayet, 2018):

- on the one hand, should crops fail or underperform, heat producers purchasing the biomass fuel must be compensated for the failed supply, and they need to source emergency fuel supplies from - presumably more expensive sources.

- on the other hand, a lower yield means less $\mathrm{CO}_{2}$ sequestered, thus missing $\mathrm{CO}_{2}$ reductions must be covered from different sources (e.g., carbon trading), leading to cost increases.

In light of the above, only woody energy crops will be considered feasible for carbon sequestration.

Harvest uncertainties is virtually negligible, provided appropriate techniques are used on the plantation. Minor variations in the calorific values may be attributed to the differences in dry mass.

Decarbonization calculations are performed using the IPCC's default method. In essence, this means that
- energy produced may be expressed as the product of the yield and the calorific value;

- it may be assumed that the energy generated is used to replace natural gas, thus annually prevented $\mathrm{CO}_{2}$ emissions are calculated as the product of the emission coefficient of natural gas and the quantity of energy produced.

\section{3 $\mathrm{CO}_{2}$ offsetting by the establishment of a photovoltaic (PV) farm}

Electricity generation using photovoltaics has experienced stellar growth during the past years, with technology costs plummeting as the primary driving force. The International Energy Agency has predicted that PV technology will be a defining element in the future of sustainable energy provision by the 2020 s.

Nevertheless, the integration potential of photovoltaic systems into the electric grid is limited. This is partially a consequence of the limited receptive capacity of the grid, but a further obstacle is that systemic expedience is not being considered in either the planning and implementation phase, or in the operating phase. (Kapros, 2017).

It is therefore proposed that $\mathrm{CO}_{2}$ offsetting takes place - at least in part - through the implementation of an innovative and demonstrative model of an integrated photovoltaic generator and battery park.

This would effectively make the proving ground a consumer of solely renewable energy, whilst $\mathrm{CO}_{2}$ offsetting would be achieved simultaneously.

By assessing a number of PV projects implemented across Hungary, the specific surface area required for photovoltaic generation (energy production per hectare) could be determined. Furthermore, based on extensive literature review, annual operating hours were determined, using data on solar exposure, cloud cover and daily and seasonal global radiation. Calculations are based on the IPCC's methods, and the emission coefficient is taken to be equivalent to the value published in Hungary's National Inventory Report.

Based on the initial figures of Table 6, the decarbonization potential of the PV farm was calculated at $184.8 \mathrm{t}\left[\mathrm{CO}_{2}\right] /$ year/hectare in average.

Table 6 Basic parameters used to design the PV farm (own calculations)

\begin{tabular}{|c|c|c|c|c|}
\hline \multicolumn{2}{|c|}{ Specific land needs } & \multicolumn{2}{|c|}{ Occupancy hours } & \multirow[t]{2}{*}{ Emission factor } \\
\hline Average & \pm & Average & \pm & \\
\hline \multicolumn{2}{|c|}{ [MW/ha] } & \multicolumn{2}{|c|}{$[\mathrm{h} /$ year $]$} & {$\left[\mathrm{t} \mathrm{CO}_{2} / \mathrm{MWh}\right]$} \\
\hline 0.48 & $15 \%$ & 1100 & $10 \%$ & 0.35 \\
\hline
\end{tabular}




\section{Summary, conclusions}

The $\mathrm{CO}_{2}$ equivalent annual emissions of diesel and petrol consumption were assessed (as a product of fuel demand and conversion factors). It can be comprehensively deduced that, by relying on the estimated data for test operations, and based on the hypothetical, relative consumption and diesel-petrol ratios, and using the conversion factors in the standard, the annual aggregate $\mathrm{CO}_{2}$ equivalent emissions of the test track, using the "Tank-to-Wheels" approach (vehicle movement) amount to 226.2 tons.

Carbon offsetting provides an important opportunity for the practical implementation of carbon footprint calculations. Our estimation shows the long term carbon effect of this unique investment and can be a good example for further investigations.

Considering the experiences in Hungary, the endowment of Zala County, and the opportunities of the proving ground, the following three $\mathrm{CO}_{2}$ offsetting options are evaluated:

- $\mathrm{CO}_{2}$ sequestration with forestation and green surface development;

- $\mathrm{CO}_{2}$ offsetting by energy crop plantation and heat generation;

- $\mathrm{CO}_{2}$ offsetting by the establishment of a photovoltaic (PV) farm (electricity production).

Based on the decarbonization paths, the most important deductions are the following:

- Forestation and energy crop plantation exhibit no significant difference in decarbonization potentials; the prior falls within a range of 6 to 33 tons per year per hectare, whilst the latter ranging from 11 to 30 tons per year per hectare. However, energy crop plantation comes with a number of disadvantages, which are to be considered significant (e.g., creation of heat energy demand, existing artificial fertilizer and pesticide demand). These disadvantages are not counterbalanced by the advantages, especially in comparison with the forestation approach. It is noted that

\section{References}

Ben Fradj, N., Jayet, P. A. (2018) "Optimal management of perennial energy crops by farming systems in France: A supply-side economic analysis", Biomass and Bioenergy, 116, pp. 113-121. https://doi.org/10.1016/j.biombioe.2018.06.003

Dalton, G., de la Pena, E., Vassallo; J. M., Acciaro, M. (2017) "Transport Infrastructure, Expert group report", European Commission, Brussels, Belgium. [online] Available at: https://ec.europa.eu/ transparency/regexpert/index.cfm?do=groupDetail.groupDetailDoc\&id=34586\&no=1 [Accessed: 21 September 2019] forestation merits a higher priority than the plantation of energy crops in the carbon sequestration efforts of the test track.

- The PV farm exhibits a decarbonization potential two orders of magnitude greater (141 to 374 tons per year per hectare) than the other two proposals. Considering this, installation of a PV farm as a means of carbon sequestration, is deemed justified.

As a summary Fig. 4 shows the above mentioned decarbonization potential as specific values of $\mathrm{CO}_{2}$ savings.

During the remaining stages of the research, the feasibility of a package arrangement combining both forestation and PV farm installation should be analyzed, encompassing costs and financing opportunities based on specific scaling requirements.

\section{Acknowledgement}

The research reported in this paper and carried out at the Budapest University of Technology and Economics has been supported by the National Research Development and Innovation Fund (TKP2020) based on the charter of bolster issued by the National Research Development and Innovation Office under the auspices of the Ministry for Innovation and Technology.

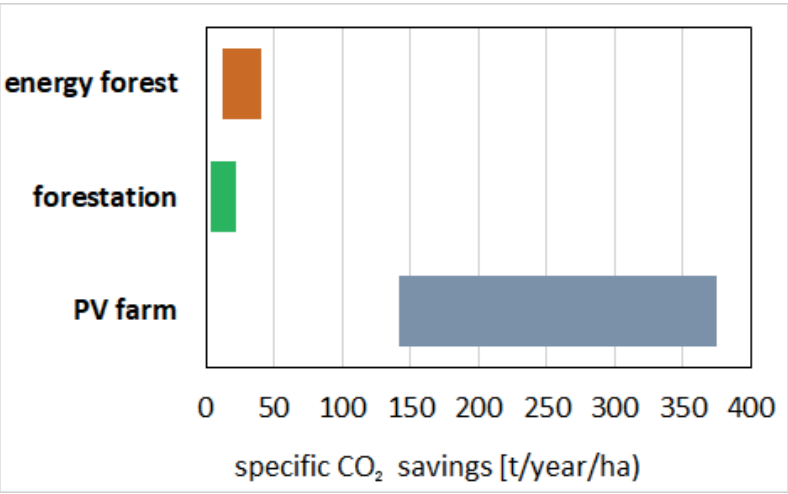

Fig. 4 Decarbonization potential (attainable maximum) (own calculations)

European Union (EU) (2013) "Commission Recommendation (COM) of 9 April 2013 on the use of common methods to measure and communicate the life cycle environmental performance of products and organisations", Official Journal of the European Union, Brussels, Belgium, Rep. 2013/179/EU.

FM (2016) "Nemzeti Erdőstratégia" (National Forestry Strategy), [pdf] Földművelésügyi Minisztérium (Ministry of Agriculture), Budapest, Hungary. (in Hungarian) Available at: https:/www. kormany.hu/download/a/1a/d0000/Nemzeti_Erdőstratégia.pdf [Accessed: 21 September 2019] 
Hungarian Central Statistical Office (HSO) "forestation rate" [online] Available at: http://www.ksh.hu/docs/hun/xstadat/xstadat [Accessed: 21 September 2019]

Hungarian Central Statistical Office (HSO) (2018) "Helyzetkép a szállítási ágazatról, 2017" (Situation of the transport sector, 2017), [pdf] Hungarian Central Statistical Office (HSO), Budapest, Hungary. Available at: https://www.ksh.hu/docs/hun/xftp/idoszaki/jelszall/ jelszall17.pdf [Accessed: 26 May 2020]

ITM (2019) "Hazai Elektromobilitási Stratégia, Jedlik Ányos Terv 2.0" (Domestic Strategy of Electromobility, Jedlik Ányos Plan 2.0), [pdf] Innovációs és Technológiai Minisztérium (Ministry of Innovation and Technology), Budapest, Hungary. (in Hungarian) Available at: https://www.kormany.hu/download/f/a9/a1000/Hazai\%20elektromobilit\%C3\%A1si\%20strat\%C3\%A9gia.pdf [Accessed: 21 July 2020]

Ivelics, R. (2006) "Minirotációs energetikai faültetvények termesztéstechnológiájának és hasznosításának fejlesztése" (Development of Cultivation Technology and Utilization of Mini Rotation Woody Crops for Energy Purposes), PhD dissertation, University of WestHungary. Available at: http://doktori.nyme.hu/147/1/IR_Disszertacio _2006.pdf [Accessed: 21 September 2019] (in Hungarian)

Kapros, Z. (2017) "Autonóm és hálózattal együttműködő fotovillamos energiatermelő rendszerek optimalizálása" (Autonomous and grid collaborative photovoltaic system optimization), $\mathrm{PhD}$ dissertation, Szent István University. (in Hungarian) https://doi.org/10.14751/SZIE.2017.030
MSZT (2013) "MSZ EN 16258:2013 A szállitás (teher és személy) energiaszükségletének és a GHG- (üvegházhatású) gázok kibocsátásának számítási és megadási módszerei" (Methodology for calculation and declaration of energy consumption and GHG emissions of transport services (freight and passengers), Magyar Szabványügyi Testület (Hungarian Board for Standardization), Budapest, Hungary.

Somogyi, Z. "CASMOFOR modell (CArbon Sequestration MOdel for FORestations)", [online] Available at: http://www.scientia.hu/casmofor/index.php [Accessed: 21 September]

Török, Á., Sípos, T., Tánczos, K. (2017) "Evaulation of Long Term Transport Emission Forecast Case Study for Hungary", In: International Scientific Conference Modern Safety Technologies in Transportation(MOSATT) 2017, Košice, Slovakia, pp. 181-184.

Transport \& Environment (2018) " $\mathrm{CO}_{2}$ Emissions from Cars: the facts" [pdf] European Federation for Transport and Environment (AISBL), Brussels, Belgium. Available at: https://www.transportenvironment. org/sites/te/files/publications/2018_04_CO2_emissions_cars_The_ facts_report_final_0_0.pdf [Accessed: 21 September 2019]

World Business Council for Sustainable Development (WBCSD) and World Resources Institute (WRI) (2004) "The Greenhouse Gas Protocol: A Corporate Accounting and Reporting Standard, Revised edition", [pdf] World Business Council for Sustainable Development and World Resources Institute, Washington, DC, USA. Available at: https://ghgprotocol.org/sites/default/files/standards/ghg-protocol-revised.pdf [Accessed: 21 September 2019] 